\title{
Chronic High Doses of Nandrolone Decanoate on Blood Cell, Lipoprotein Profile, and Liver Enzymes in Male Rats
}

\author{
Mohammad Reza Shahraki, ${ }^{1,}$ Hamideh Mirshekari, ${ }^{2}$ and Ahmad Reza Shahraki ${ }^{2}$ \\ ${ }^{1}$ Department of Physiology, Faculty of Medicine, Zahedan University of Medical Sciences, Zahedan, IR Iran \\ ${ }^{2}$ Zahedan University of Medical Sciences, Health Service Center, Zahedan, IR Iran \\ "Corresponding author: Mohammad Reza Shahraki, Department of Physiology, Faculty of Medicine, Zahedan University of Medical Sciences, Zahedan, IR Iran. E-mail: \\ m_shahrakim@zaums.ac.ir
}

Received 2015 January 6; Accepted 2015 May 14.

\begin{abstract}
Background: Nandrolone decanoate (ND) is a doping agent and it is used by athletes.

Objectives: This study was carried out to evaluate the chronic, high doses of ND administration on Blood cell, lipid profile, and Liver enzymes in male rats.

Materials and Methods: This experiment was executed on 30 wistar- Albino male rats divided, after weighing, in control, placebo, and test groups $(n=10)$. Test group received $15 \mathrm{mg} / \mathrm{kg}$ intramuscular (IM) ND for duration of 8 weeks. Group placebo received the same volume of placebo although control group did not receive any agent during the trial period. At the end, animals were anesthetized by diethyl ether, scarified, and then blood samples were collected from cervical vessels immediately. Blood cell, lipoprotein profile, and liver enzymes were measured by ordinary methods. Obtained data were analyzed by SPSS V.15, via ANOVA and Tukey test. Results were expressed as mean $\pm S D$. Statistical difference was significantly recognized by $\mathrm{P} \leq 0.05$.

Results: Results showed that AST, ALT, cell blood count, hemoglobin, hematocrite, and cholesterol values in group test were increased significantly compared to those of other groups; however, HDL value in this group decreased noticeably compared to control and Placebo groups.

Conclusions: Present study revealed that chronic high doses of ND administration alter the liver enzymes, lipid profile, and blood parameter in male rats.
\end{abstract}

Keywords: Nandrolone Decanoate, AST, ALT, Lipoprotein Profile

\section{Background}

Taken in high doses by athletes by the purpose of enhancing muscular strength in athletic performance [1], ND is a synthetic androgen. Gold et al. reported that $\mathrm{N}$ D administration in patients suffering from HIV infection improved body weight and lean body mass [2]. Saitoh et al. revealed that injection of ND into young and old mice clearly induced an increase in erythroid colonyforming units (CFU-E); erythroid burst-forming units (BFUE); and granulocytic-macrophage committed progenitor cells (CFU-GM) in bone marrow in both groups [3]. Moreover, low-dose administration of a considerable number of androgens alters hemoglobin concentrations, while producing potent hypertrophy actions in skeletal muscle [4]. The investigation showed that the use of anabolicandrogenic steroids (AAS) could also be a risk factor to toxicant-associated with fatty liver disease [5]. Combination therapy of Erythropoietin, ND and low-dose of methylprednisolone can be effective as an alternative treatment for Red Blood Cells (RBC) transfusion-dependent to the refractory anemia [6]. Solomon et al. reported that ND ther- apy reason direct increases in $\mathrm{RBC}$ mass [7] among patients suffering from chronic renal failure and were hemodialysis. The anabolic steroid ND is able to alter the muscle restore process in rats [8]. The studies showed that ND administration leads to rise in serum levels of the aspartate aminotransferase (AST), alanine aminotransferase (ALT), and alkaline phosphatase (ALP) compared to the control group [9]. ND causes considerably enhanced markers such as hematocrit in hemodialysis patients [10]. On the other hands ND expresses an anabolic effect on lean body mass (LBM) without altering the renal function [11]. The biochemical studies indicated that ND administration cause increase in serum levels of the AST, ALT, and ALP [12]. The studies revealed that the use of anabolicandrogenic steroids (AAS) could also be a risk factor to toxicant-associated fatty liver disease development [5]. The utilization of ND would agree to us a satisfactory management of anemia in addition to an improved nutritional stipulation in old male patients on dialysis [13]. 


\section{Objectives}

Since ND is a doping agent and used by athletes, this survey was carried out to evaluate the chronic of high doses of ND on Blood cell, lipid profile, and Liver enzymes in male rats.

\section{Materials and Methods}

The present study was performed on 20 mature male Wistar-Albino rats, weighing $180 \pm 30$ g; ages were 5 - 7 months separately housed in cages (one rat per cage). Animals had free access to water and food. Rats were maintained in a room at $24 \pm 2{ }^{\circ} \mathrm{C}$ with a fixed 12 hours artificial light period (Timer Model: SUL180a, AC220V. China, 6 Am to $6 \mathrm{Pm})$. Rats were divided in control(C), placebo $(\mathrm{P})$ and test (T) groups $(\mathrm{n}=10)$ as following: Group T received $15 \mathrm{mg} / \mathrm{kg}$ iM of ND on a daily basis for eight weeks. Group P did the same volume of sterile Peanut oil (oil vehicle) during the trial period but group $C$ did not receive any agents in experimental period [14]. All groups received standard rodent diet and tap water during handling period. ND was purchased from Caspian pharmaceutics cooperation and was placed in suitable temperature. All injections were performed between 8-11 o'clock a.m. At the end of experimentation, rats were fasted for 14 - 16 hours, and then all were sacrificed by cervical decapitation under high dose of diethyl ether anesthesia. Blood samples were collected from cervical vessels immediately. Cell bloods were counted by coulter counted. Serum high density lipoprotein (HDL); total cholesterol (TC) and triglyceride (TG) levels; serum AST; and ALT activity were measured by ordinary methods (Technicon, USA). Low density lipoprotein (LDL) was calculated by Friedwald formula [15]. Data were analyzed by SPSS V.17, using ANOVA and Tukey statistical tests. Results were expressed as mean $\pm \mathrm{SD}$. Statistical differences were significantly recognized by $\mathrm{P} \leq 0.05$. These experiments on animals were carried out in accordance with recommendations from the pronouncement of Helsinki and internationally conventional principles for the use of experimental animals, and they received institutional ethical approval from the committee for Animal Research of Zahedan University of Medical Sciences.

\section{Results}

After 8 weeks of handling, there were no significant differences $(\mathrm{P}>0.05)$ in LDL and triglyceride values between control and test group; although, HDL value in group $\mathrm{T}$ decreased substantially compared to that of group C (Table 1 , $\mathrm{P}=0.007)$. On the other hand, the serum AST and ALT activity,and cholesterol values in animals treated with ND were increased significantly $(\mathrm{P}=0.001, \mathrm{P}=0.02$, $)$ in comparison with those of group C (Table 1).

Based on ANOV and Tukey testes, AST, ALT and cholesterol values in male group $\mathrm{T}$ were increased significantly compared to those of other groups but HDL value in group $\mathrm{T}$ was significantly decreased compared to that of other groups $(\mathrm{P}<0.05)$. In addition, Blood cell parameter, final weight, food , and water intake in group $T$ rose sharply compared to those of group $\mathrm{C}$ and $\mathrm{P}$ (Table 2, $\mathrm{P}<0.05$ ). The comparison of other parameters values in all groups did not showed any differences.

Based on ANOV and Tukey testes: Blood parameter, Final weight, Food, and Water intake values in group T were significantly increased compared to those of other groups $(\mathrm{P}<0.05)$.

\section{Discussion}

Anabolic-androgenic steroids (AAS) such as ND are artificial androgen agents used in high doses by athletes to enhance muscular potency and performance. Vieira et al. in a biochemical studies investigated that one time administration of dose-dependent ND leads to increases of serum levels activity of AST, ALT, and ALP in wistar male rats .In addition, the Kupffer cells in portal space and in the liver parenchyma increased significantly compared to control group [12]. Clark et al. studies in 2005 revealed that blood biochemical analysis had shown the symptoms of acute hepatitis [16] for a healthy 40-year-old man using ND. In addition, Stimac et al. reported that bilirubin, AST, ALT and ALP level were higher than normal rang [17] for a 26-year-old male bodybuilder who administered high doses of androgenic/anabolic steroids (500 mg intramuscularly, twice weekly). Pertusi et al. investigated that, in male bodybuilder who uses anabolic steroids, the blood serum biochemistries liver enzymes such as AST, ALT, and creatine kinas (CK) levels showed higher values compared to those of male bodybuilder who did not consume anabolic steroid [18]. In addition, studies revealed that blood chemistry profiles such as AST, ALT are higher than those of controls [19] in case of taking self-directed regimens of anabolic steroids bodybuilders $(n=15)$. Our findings in the present study indicated that eight - week ND administration causes significantly increased serum AST and ALT activity compared to those of control groups. Likewise, they are confirmed by previous study. In addition, our results revealed that HDL value in group T declined noticeably compared to other groups but cholesterol values in this group were significantly higher than group $C$ and $\mathrm{P}$. Previous study revealed that AAS administration provoked protein synthesis, and fiber type composition in skeletal 
Table 1. Chronic, of High Doses of ND on Liver Enzymes and Serum Lipid Profiles in Male Rats $(\mathrm{N}=10)$

\begin{tabular}{|c|c|c|c|c|}
\hline \multirow[t]{2}{*}{ Parameters } & \multicolumn{3}{|c|}{ Groups } & \multirow[t]{2}{*}{ P Value } \\
\hline & $\mathrm{C}$ & $\mathbf{P}$ & $\mathbf{T}$ & \\
\hline LDL, $\mathbf{m g} / \mathbf{d L}$ & $8.9 \pm 3.9$ & $9.1 \pm 2.8$ & $11.2 \pm 7.1$ & $>0.05$ \\
\hline HDL, mg/dL & $40.1 \pm 8.2$ & $38.1 \pm 7.6$ & $22.7 \pm 3.6^{\mathrm{a}}$ & $<0.007$ \\
\hline Chol, mg/dL & $54.1 \pm 11.4$ & $55.2 \pm 10.7$ & $64.4 \pm 6.2^{\mathrm{a}}$ & $<0.02$ \\
\hline TG, mg/dL & $65.2 \pm 13.4$ & $63.2 \pm 12.7$ & $61.4 \pm 12.1$ & $>0.05$ \\
\hline AST, iu/L & $169.7 \pm 4.24$ & $172.1 \pm 6.24$ & $255 \pm 32^{\mathrm{a}}$ & $<0.001$ \\
\hline ALT, iu/L & $71.6 \pm 8.9$ & $69.2 \pm 7.7$ & $84.3 \pm 3.87^{\mathrm{a}}$ & $<0.02$ \\
\hline
\end{tabular}

Table 2. Chronic, of High Doses of ND on Blood Cells, Food and Water Intake in Male Rats $(\mathrm{N}=10)$

\begin{tabular}{|c|c|c|c|c|}
\hline \multirow[t]{2}{*}{ Parameters } & \multicolumn{3}{|c|}{ Groups } & \multirow[t]{2}{*}{ P Value } \\
\hline & C & $\mathbf{P}$ & $\mathbf{T}$ & \\
\hline Hemoglobin, g/dL & $13.1 \pm 1.8$ & $12.8 \pm 2.1$ & $16.4 \pm 3.1^{\mathrm{a}}$ & $<0.03$ \\
\hline Hematocrit,\% & $43.2 \pm 3.3$ & $42.7 \pm 2.9$ & $48.6 \pm 4.1^{\mathrm{a}}$ & $<0.01$ \\
\hline $\mathrm{RBC}, \times 10^{6}$ & $6.21 \pm 2.17$ & $6.81 \pm 1.62$ & $8.68 \pm 1.23^{\mathrm{a}}$ & $<0.03$ \\
\hline $\mathrm{WBC}, \times 10^{3}$ & $3.6 \pm 0.6$ & $4.2 \pm 0.4$ & $5.3 \pm 1.23^{\mathrm{a}}$ & $>0.01$ \\
\hline Platelets, $\times 10^{3}$ & $724 \pm 76.6$ & $678 \pm 68.4$ & $939.9 \pm 147.9^{\mathrm{a}}$ & $<0.001$ \\
\hline Final weight, $g$ & $212.8 \pm 12.4$ & $215.2 \pm 11.1$ & $236 \pm 11.2^{\mathrm{a}}$ & $<0.02$ \\
\hline Food intake, $\mathbf{g}$ & $13.2 \pm 3.1$ & $12.9 \pm 2.8$ & $15.7 \pm 2.7^{\mathrm{a}}$ & $<0.03$ \\
\hline Water intake, mL & $40.2 \pm 5.6$ & $41.7 \pm 4.8$ & $48.6 \pm 6.6^{\mathrm{a}}$ & $<0.001$ \\
\hline
\end{tabular}

muscles cell and it causes increases body weight in wistar rats [20]. Gold et al. reported that that N D administration in patients suffering from HIV infection causes improved body weight and lean body mass [2]. Our results in the present study similar to previous study indicated that eight weeks administration of ND causes significantly increased body weight. Frankenfeld et al. reported that administration of supraphysiological doses of ND alters glucose metabolism and lipid profile in wistar rats [21]. Experimental study indicated that ND administration in hemodialysis patients has beneficial effects but alters lipid profile by increasing the serum cholesterol and triglyceride [22]. Our findings showed that HDL value in group $\mathrm{T}$ was significantly increased compared to other groups and are in agreement with those of lectures and they showed that supraphysiological ND administration for eight weeks in male rats alters the lipid profile. Ghorbanihaghjo et al. investigated that hemoglobin and hematocrit value in hemodialysis patients improved after ND administration [22]. Urhausen in 2003 showed that Blood parameters (hemoglobin, leucocytes and platelets) in 32 male bodybuilders and power lifters who consumed anabolic steroids were significantly higher than references [23]. In addition, they showed that, in this group, AST and ALT value were over limited [23]. Moreover, our finding revealed that that eight- week high dose of ND administration causes increased blood cell in rats. This finding is completed with Saitoh et al. who reported that injection of ND into young and old mice induced an increase in erythroid colony-forming units, erythroid burst-forming units, and granulocytic-macrophage committed progenitor cells in bone marrow in both groups [3]. Our finding revealed that blood parameters in group $\mathrm{T}$ were increased substantially compared to that of $\mathrm{C}$ and P groups. This section of finding is similar to previous studies. Our finding in the present study revealed that chronic administration of ND causes increased liver toxicity in male rats by altering the blood parameter, gain of weight, food and water intake in male rats. 


\section{Acknowledgments}

This study was financially supported by the deputy research center at Zahedan University of Medical Sciences (project No.: 720). We are grateful to Mahnaz Shahrakipour for her kind cooperation.

\section{Footnote}

Funding/Support: Zahedan University of Medical Sciences.

\section{References}

1. Clark AS, Mitre MC, Brinck-Johnsen T. Anabolic-androgenic steroid and adrenal steroid effects on hippocampal plasticity. Brain Res. 1995;679(1):64-71. [PubMed: 7648266].

2. Gold J, High HA, Li Y, Michelmore H, Bodsworth NJ, Finlayson R, et al. Safety and efficacy of nandrolone decanoate for treatment of wasting in patients with HIV infection. AIDS. 1996;10(7):745-52. [PubMed: 8805865].

3. Saitoh T, Morimoto K, Kumagai T, Tsuboi I, Aikawa S, Horie T. Comparison of erythropoietic response to androgen in young and old senescence accelerated mice. Mech Ageing Dev. 1999;109(2):125-39. [PubMed: 10515662].

4. Yarrow JF, Conover CF, McCoy SC, Lipinska JA, Santillana CA, Hance $\mathrm{JM}$, et al. 17beta-Hydroxyestra-4,9,11-trien-3-one (trenbolone) exhibits tissue selective anabolic activity: effects on muscle, bone, adiposity, hemoglobin, and prostate. Am J Physiol Endocrinol Metab. 2011;300(4):E650-60. doi: 10.1152/ajpendo.00440.2010. [PubMed: 21266670].

5. Schwingel PA, Cotrim HP, Salles BR, Almeida CE, dos Santos CJ, Nachef $B$, et al. Anabolic-androgenic steroids: a possible new risk factor of toxicant-associated fatty liver disease. Liver Int. 2011;31(3):348-53. doi: 10.1111/j.1478-3231.2010.02346.x. [PubMed: 21040407].

6. Tsiara SN, Chaidos A, Gouva M, Christou L, Panteli K, Kapsali E, et al. Successful treatment of refractory anemia with a combination regimen containing recombinant human erythropoietin, lowdose methylprednisolone and nandrolone. J Exp Clin Cancer Res. 2004;23(1):47-52. [PubMed: 15149150].

7. Solomon LR, Hendler ED. Prospective controlled study of androgen therapy in the anemia of chronic renal disease: effects on iron kinetics. Acta Haematol. 1988;79(1):12-9. [PubMed: 3124456].

8. Piovesan RF, Fernandes KP, Alves AN, Teixeira VP, Silva Junior JA, Martins MD, et al. Effect of nandrolone decanoate on skeletal muscle repair. Int J Sports Med. 2013;34(1):87-2. doi: 10.1055/s-0032-1311652. [PubMed: 22791621].

9. do Carmo CA, Goncalves AL, Salvadori DM, Maistro EL. Nandrolone androgenic hormone presents genotoxic effects in different cells of mice. J Appl Toxicol. 2012;32(10):810-4. doi: 10.1002/jat.1701. [PubMed: 21717486].
10. Barton Pai A, Chretien C, Lau AH. The effects of nandrolone decanoate on nutritional parameters in hemodialysis patients. Clin Nephrol. 2002;58(1):38-46. [PubMed: 12141405].

11. Eiam-Ong S, Buranaosot S, Eiam-Ong S, Wathanavaha A, Pansin P. Nutritional effect of nandrolone decanoate in predialysis patients with chronic kidney disease. J Ren Nutr. 2007;17(3):173-8. doi: 10.1053/j.jrn.2007.01.001. [PubMed: 17462549].

12. Vieira RP, Franca RF, Damaceno-Rodrigues NR, Dolhnikoff M, Caldini EG, Carvalho CR, et al. Dose-dependent hepatic response to subchronic administration of nandrolone decanoate. Med Sci Sports Exerc. 2008;40(5):842-7. doi: 10.1249/MSS.0b013e3181666fic. [PubMed: 18408615].

13. Gascon A, Belvis JJ, Berisa F, Iglesias E, Estopinan V, Teruel JL. Nandrolone decanoate is a good alternative for the treatment of anemia in elderly male patients on hemodialysis. Geriatr Nephrol Urol. 1999;9(2):67-72. [PubMed:10518249].

14. Tugyan K, Ozbal S, Cilaker S, Kiray M, Pekcetin C, Ergur BU, et al Neuroprotective effect of erythropoietin on nandrolone decanoateinduced brain injury in rats. Neurosci Lett. 2013;533:28-33. doi: 10.1016/j.neulet.2012.10.004. [PubMed: 23063952].

15. Friedewald WT, Levy RI, Fredrickson DS. Estimation of the concentration of low-density lipoprotein cholesterol in plasma, without use of the preparative ultracentrifuge. Clin Chem. 1972;18(6):499-502. [PubMed: 4337382]

16. Clark BM, Schofield RS. Dilated cardiomyopathy and acute liver injury associated with combined use of ephedra, gamma-hydroxybutyrate and anabolic steroids. Pharmacotherapy. 2005;25(5):756-61. [PubMed: 15899737].

17. Stimac D, Milic S, Dintinjana RD, Kovac D, Ristic S. Androgenic/Anabolic steroid-induced toxic hepatitis. J Clin Gastroenterol 2002;35(4):350-2. [PubMed: 12352300].

18. Pertusi R, Dickerman RD, McConathy WJ. Evaluation of aminotransferase elevations in a bodybuilder using anabolic steroids: hepatitis or rhabdomyolysis?.JAm Osteopath Assoc. 2001;101(7):391-4. [PubMed: 11476029].

19. Dickerman RD, Pertusi RM, Zachariah NY, Dufour DR, McConathy WI Anabolic steroid-induced hepatotoxicity: is it overstated?. Clin J Sport Med. 1999;9(1):34-9. [PubMed: 10336050].

20. Fontana K, Campos GE, Staron RS, da Cruz-Hofling MA. Effects of anabolic steroids and high-intensity aerobic exercise on skeletal muscle of transgenic mice. PLoS One. 2013;8(11):e80909. doi: 10.1371/journal.pone.0080909. [PubMed: 24260508].

21. Frankenfeld SP, de Oliveira LP, Ignacio DL, Coelho RG, Mattos MN, Ferreira AC, et al. Nandrolone decanoate inhibits gluconeogenesis and decreases fasting glucose in Wistar male rats. $J$ Endocrinol. 2014;220(2):143-53. doi:10.1530/JOE-13-0259. [PubMed: 24403377].

22. Ghorbanihaghjo A, Argani H, Rohbaninoubar M, Rashtchizadeh N Effect of Nandrolone Decanoate on serum lipoprotein (a) and its isoforms in hemodialysis patients. Lipids Health Dis. 2004;3:16. doi: 10.1186/1476-511X-3-16. [PubMed: 15225379]

23. Urhausen A, Torsten A, Wilfried K. Reversibility of the effects on blood cells, lipids, liver function and hormones in former anabolicandrogenic steroid abusers. J Steroid Biochem Mol Biol. 2003;84(23):369-75. [PubMed: 12711025]. 